\title{
Innovation and Practice of Cultivation Mode of Internationally Visionary Professional Managers in Leisure Sports-Case of Sichuan Tourism University
}

\author{
Luo Rui \\ Sichuan Tourism University, Chengdu, Sichuan, 610100, China \\ 763049267@qq.com
}

Keywords: Leisure Sports, International Vision, Proemailfessional Manager, Talent Cultivation Abstract. This work adopted literature consultation, specialist interview as its research methodologies. With the globalization of leisure sports and substantial emergence of market capital, some measures were taken to meet capital market's demand for high-level professional managers in leisure sports. For example, Sichuan Tourism University specified the internationalization, marketization, specialization, application orientation and comprehensiveness as the key elements. Besides, it systematically analyzed the innovation and practice of cultivation orientation, mainline and methods.

\section{Introduction}

As a new major, leisure sports has been the research hotspot of sports workers at colleges and universities since its introduction to China in 2006. In May 2009, an agreement on its cultivation goals was reached in Leisure Sports National Seminar of Colleges \& Universities of Sports. The goals are to cultivate compound talents who are able to manage, guide and serve leisure sports. With the structure adjustment of capital market and the subsequent influx of funds, leisure sports industry is experiencing a phenomenal growth. Facing the substantial demand for technical and managerial talents, it is difficult to find high-level visionary professional managers which can operate and manage capitals. Therefore, it is urgent for leisure sports colleges and universities to establish market-oriented talent cultivation mode. In that case, variable cultivation can be realized according to market development. Sichuan Tourism University was taken as an example in the work to analyze talents cultivation in leisure sports for other schools' reference.

\section{Object \& Methodology of the Research}

Study Object. The study object is the talents training scheme in leisure sports of Sichuan Tourism University. This work aims to study and construct the innovation and practice of the cultivation mode of internationally visionary professional managers in leisure sports.

Research Methodology. This study is based on the papers, reports and subjects researches relating to construction of the major, talents cultivation, leisure sports industry, etc.

Precious experience was learned from the interviews with relevant theoretical researchers, scholars and others, who are responsible for talents cultivation of leisure sports at colleges or universities in a long term. Meanwhile, surveys on the demand for vocational abilities were also performed by visiting the administrators of leisure sports enterprises and association members.

\section{Results \& Analyses}

Cultivation Orientation of High-level Application-oriented Talents in Leisure Sports. The following three elements should be taken into consideration, because cultivation orientation is the key to cultivation mode of talents in leisure sports. The first one is the required vocational abilities for market-oriented positions. The second is the characteristics of local resources and the disciplinary advantages of schools. The last one is the homogeneous competition and specialty characteristics. 
Nowadays, leisure sports have become an important entertainment program for people with the increasing leisure awareness. Broad and general company products should be changed for more specialized ones in order to meet the personalized and specialized demand for high-level and innovative leisure sports. With the influx of substantial capitals, there are lots of leisure sports companies offering professional service of superior quality. Influenced by the international management concept, they introduce and improve international products. In addition, these enterprises recruit senior management talents with professional backgrounds, and appoint them as their professional administrators or operators. At present, talents cultivation in leisure sports mainly focuses on technical service rather than managerial skills and marketing across colleges and universities in China. What's worse, it scarcely involves the financing and public relations abilities needed by professional managers.

Therefore, the cultivation orientation of leisure sports major sets out to equip the future high-level application-oriented professional managers with the following elements in Sichuan Tourism University. Following aspects are included: superior ideological and moral qualities, solid theoretical basics, instructive service ability, marketing and managerial skills, financing and public relations capacities, and international vision in this field.

Essential Elements in Cultivation Mode of High-level Application-oriented Talents in Leisure Sports. There exist the generality of comprehensiveness, specialization and application-orientation in the entire cultivation mode of leisure sports talents across the country. That is to say, this mode attaches great importance to the comprehensiveness of knowledge, the specialization of vocation, and practical abilities of theories and technologies. However, there are also some problems in this mode. At colleges and universities, the "characteristics" of leisure sports majors mainly concentrate on several programs, such as fitness, outdoors, water sports, golf, etc. The first problem is how to diversify them with the help of schools' disciplinary advantages combined with the regional economic development. The second one is how to manifest the marketability of these majors under the constraints of institutional mechanism. The third one is how to determine the essence of students' application ability so as to improve their competitiveness. The fourth is how to balance the learning time allocation between basic subjects and specialized professional courses in order to cultivate their comprehensive abilities.

Sichuan Tourism University confirmed that its cultivation goal is to train high-level, application-oriented and internationally visionary talents in leisure sports. In the context of internationalization of leisure sports industry, it should realize variable cultivation, taking advantage of local resources, industrial demand, and its specialty characteristics. The core elements of talents cultivation mode contain internationalization, marketization, specialization, application orientation and comprehensiveness.

Firstly, this school launches co-training and study tours mechanism with overseas universities by bringing in internationally advanced courses. Besides, students' international vision is cultivated by channeling international practice, internship and practical training. Secondly, a cultivation mechanism is established based on the marketization of curriculum content and teachers. It aims to evade the disjunction, resulting from institutional restrictions, between talents cultivation mode and market. Thirdly, specialty characteristics stand out with the diversification of cultivation goals and the specialization of major courses. Fourthly, students are provided with the following programs to cultivate their practical application ability, especially in the specialized directions. The programs include practical training in vacations, regular social practice of associations and enterprises, competitions inside / outside schools, innovations, internship, etc. Finally, importance is attached to students' comprehensive ability according to the principle of "broad professional knowledge and solid basics". More than a third of the class time is allocated to public compulsory courses and basic disciplines.

Constructing Applied Leisure Sports Prominent Talent Pattern. Mainline of leisure sports talents training is the primary technical line to cultivate people. During the training period, it also embodies the time node of different core elements. The mainline reflects how the students build capacity to improve their quality when studying knowledge. 
Three-stage progressive method is used in Sichuan tourism and leisure sports. The method includes basic education, professional development and ability improvement. When studying professional skills, the students gain the employ ability. In the training, competence of professional managers and special ability will integrated and keep pace with each other.

Therefore, basic courses are mainly arranged in the first year through large educational platform. For professional managers, courses in the second school year include management, marketing, finance, and public relations. Special education is created at the same time.

To improve the students' practical application ability, professional managers' courses are set with social practice and vacation training in the third year. Students will improve their ability in the seventh and eighth semester, so a one-year professional practice is needed. The school will promote projects such as study tours, joint training and international internships.

Table 1 Mainline of training leisure sports prominent talent

\begin{tabular}{cccc}
\hline Training stage & Main content & ability & semester \\
\hline Basic stage & $\begin{array}{c}\text { Public compulsory subject } \\
\text { and foundation }\end{array}$ & Subjects foundation & 1 and 2 \\
$\begin{array}{c}\text { Development } \\
\text { stage }\end{array}$ & $\begin{array}{c}\text { Professional compulsory, } \\
\text { special education and real } \\
\text { training practice }\end{array}$ & $\begin{array}{c}\text { Professional } \\
\text { foundation }\end{array}$ & $3,4,5$ and 6 \\
$\begin{array}{c}\text { Improving } \\
\text { stage }\end{array}$ & $\begin{array}{c}\text { Internship and study tours } \\
\text { aboard }\end{array}$ & Practical application & 7 and 8 \\
\hline
\end{tabular}

In most colleges, physical education course is designed in accordance with "platform and module education" now. Basic courses as well as specialized courses are arranged after general education on a large platform. In fact, it is easier to grasp course progress when the program is divided into three course including basic education, professional development and ability enhancement. On this basis, it is more conducive to organize courses through designing the "platform and module education ".

Basic Education Courses. Basic education aims to cultivate the overall quality of students. There are 3 categories of courses: Liberal capacity, culture, and discipline-based course. Liberal capacity courses consist of English, Computer, Practical Writing and Social Etiquette.

Cultural Training courses are made up of several courses such as Morality and Legal Basis and Introduction to Chinese Modern History. Besides, it also includes Mao-Deng and The Important Thought of Three Represents, University Language and Chinese classics.

Basic courses can lay a good theoretical basis for professional development. Its main courses refer to Basic Leisure Science, Sociology Leisure, Leisure Sports Introduction, Sports Anatomy, Exercise Physiology, Sports Psychology and Ideological Guiding.

Courses in Professional Development Stage. Professional development stage includes 3 professional links including theory, technique and electives. Management ability courses consist of Leisure Sports Management, Sports Economics, and Sports Marketing Research Methods. To enhance marketing ability, students study Leisure Sports Marketing, Leisure Sports Consumer Psychology and Sports Planning. Financial management capacity-building courses include Leisure Sports Club Finance Management. Public relations capacity-building courses are also studied, including Social Etiquette, Sports Public relations. We also arrange a sports club management comprehensive course with 4 credits.

Fashion casual sport is the main part of professional and technical courses. It is a special course system connected firmly with market. The professional and technical courses refer to golf, rock climbing, outdoor sports, bodybuilding, beach volleyball, tennis, diving, floor ball, billiards, outdoor survival training, and RV driving. The courses above can help students build the basic professional ability in multi-view structure. 
Selective Courses are the main aspects of students' employment ability. Combining with professional features, our university offers 5 elective courses including outdoor sports, water sports, bodybuilding, golf, and small ball sports. Taking Chengdu as the center, the course involves Beijing ,Shanghai and Guangzhou.

Courses in Capacity Building Phase. Students' applied ability is paid attention to during capacity building phase. Five sections are arranged: social practice, innovation and entrepreneurship, training, internships, and thesis. In the fourth and fifth semesters, there are respectively 2 credits in social practice arrangements. In the third and fourth semesters, 4 credits are added to holiday training programs. Students enter internship positions combining with enterprise employing time node. They will get 12 credits during one year after the sixth semester. Thesis is designed for six credits.

Training Leisure Sports Professional Manager with an International Perspective. The internationalization of course is an important way to gain international vision. Generally, total nationalization can not be achieved as a result of the P.E. teachers and students' poor foundation in colleges. As the professional competence in core course, selective courses are regarded as a breakthrough to achieve internationalization. Firstly, world-class courses are achieved by the introduction of foreign culture courses and assessment system.

Secondly, foreign practice content is arranged in the practical aspects of the selective courses. We introduce bodybuilding fitness training system in Asia Institute. In outdoor sports, we introduce the French outdoor instructor training certification system, WMA North American wild rescue system and Krabi climbing training. IGQ training system in New Zealand is applied to golf. Water sports system introduces diving PADI, Thailand dolphin Bay Dive training and so on.

Study tour mechanism consists of foreign universities and regional colleges. Five international study tour destinations are established for tours ranging from 3 to 6 months. Study tour programs are conducted regularly in the fourth semester. A tour project is established with historical Elmwood College in Scotland. Outdoor sports project is developed with the French University of Savoy- the resort of that. Our school cooperates with Taiwan Cheng Shiu University to found a leisure sports industry service and a management study tour project.

Students can understand advanced concepts in the specific field through project-based study tour. Study tour can cultivate high-level talents and develop an international perspective of students.

Building Innovative Practice Mechanisms into "Pluralism". The oneness of school teaching subjects is broken, with the establishment of the "five-in-one" "pluralism" talents training system involving in business, industry, community, and business platform. Functions for knowledge transmission, practice exercise of business, qualification training in industries, social evaluating, and guidance towards platforms are in full use to provide the learning and training platforms, as well as the opportunities created for practices. As a result, the ability of "application-orientation" for students can be cultivated.

Realizing Talents Training Mode of Collegiate System Using “One Major for One Business”. Collegiate talents training mode of "one major for one business" is adopted in the university. In other words, one business is introduced to one industrial field according to the choices of majors. As a result, the independent college cooperated by school and business will be set up. In this way, the business capital can be used to improve the conditions of school-running hardware so as to share the business faculty, curriculum, and market resources together. Meanwhile, the venues built by the business are open for public in the spare time. Students can join in the club operations team under the guidance of the business mentors, forming a characteristic and application-oriented training mode of "combining work with study".

Cultivating Localized Characteristic with Elective. Elective (direction) is an important means of developing the employability of students. Currently, cultivation orientations for directions of elective in the leisure sports of universities are basically concentrated in the technical guidance, services, and managers of the clubs. It covers top bodybuilding, water sports, outdoor sports, golf and so on. Similarly, the 5 elective directions, i.e., top bodybuilding, water sports, outdoor sports, golf and small 
ball sports, have been set up to meet the needs of the markets. In order to highlight the differences in development, the bodybuilding direction is combined with professional advantages of cooking, food science. The goal is to cultivate senior private fitness instructors with the abilities to match the sport and deploy the sports nutrition. In respect to the water sports, it has been the first to cultivate the tourism management talents among institutions of higher education in China. Students in this direction are capable of developing and promoting international diving tourism products. The outdoor sports are mainly training the top talents skilled in operation and guidance. The students have equipped with international visions and good at outdoor professional English with extensive practical experience. The golf aims at cultivating the talents who can provide technical guidance to sports and promote the sports games. The small ball sports, with their advantages in the Internet, will cultivate talents of managements who have the ability of thinking for "Internet +". Next step, we will start the directions of traveling by limo, mountain tourism planning, as well as organizing and managing the sports events.

Establishing Perfect Practice System. The construction of practice teaching system is an important platform used by students to change knowledge into abilities. It is also the significant step for the training goal of application-oriented top talents in leisure sports to ultimately achieve. The practice teaching system are divided into intramural practice system and external practice system.

Through intramural practice teaching system, we could undertake sorts of sports events, activities organized by governments at all levels, associations, businesses, as well as professional teaching competitions, activities. As a result, there will be more opportunities created for students to practice. For example, the Asian Cup Climbing Championship, Nationwide College Students Climbing Championship, Nationwide College Students Orienteering Championship are hosted. Meanwhile, students are encouraged to engage in the application of innovative entrepreneurship programs, and at least 10 programs are supported to be found each year.

The external practice teaching system mainly consists of social practice, vacation training, and practice. Social practice is directly brought into the training programs, which has been used to set the credit link in the form of fixed content, and fixed time. As a consequence, the comprehensive abilities and the application ability of students will be improved. For example, each year students were regularly organized to participate in the work of planning and organization in the international Golf Tour at the Foothills Golf International Golf Club, the National Fitness Climbing Conference organized by the Mountaineers Club of Sichuan Province, and the "Yang Guilin" family bike race. Vacation training is also an important part of the external practice system. Sophomore and junior are arranged to practice in a real position of the companies for $1-2$ months during winter and summer vacation. For example, joining the "Xiling Snow Mountain winter training projects," or "summer swimming training projects of management center in Chengdu ". In the practice stage, schools and internships establish a clear assignment of responsibility training mechanism with college-enterprise cooperation. The business mentors are hired to give the internship students "apprenticeship" education, eliminating the "labor-style" practice.

\section{Conclusions}

Internationalization development of leisure sports is the historical experience from abroad. The application-oriented top talents should be cultivated with international views, which is a new trend for training and developing the talents in leisure sports of colleges.

The talents training mode should be built with internationalization, marketization, characteristic, application-orientation, and comprehensiveness, which will expand the differentiation development connotation of the colleges. Therefore, it will form various kinds of training characteristic.

The "five-in-one" "pluralism" talents training system involves in school, business, industry, community, and business platform. It is helpful to solve the marketability during the development of leisure sports, eventually forming the training system using the "market requirements oriented".

The "basic education+ professional development+ ability promotion" tiered progressive mainline for the talent training should be observed, which contributes to the arrangements of the course links. In 
this way, conflicts between comprehensive abilities and core competitiveness faced by students can be solved effectively, thus promoting developments of scientization for vocational ability cultivation.

The elective course link becomes breakthrough point of the cultivation for application-oriented abilities in leisure sports. Therefore, the training goals of the elective course should be accurately

positioned, while the advanced connotation in them should be established, which is the key for the overall goals.

\section{References}

[1] Luo Rui, et al. Leisure Sports Talents Training Mode. Journal of Sichuan Tourism University, $2014,(5)$

[2] Liu Jie, Zhang Hongxia, et al. Exploration of Building "Big Platform - Wide Caliber" Talents Training Mode of Sports Science, 2006, 27 (4)

[3] Li Xiangru, et al. Reflections on the Construction of Leisure Sports Professional in Leisure Vision. Journal of Capital University of Physical Education and Sports, 2009, (2): 180-184

[4] Jin Yinri, Li Xuewu, Wei Zhiqiang, et al. Investigation and Analysis on Leisure Sports Talents Training in Sports Colleges. Journal of Shanghai University of Sport, 2010, (3): 88-91

[5] Guo Xiujin, et al. Comparative Study of the Construction of Leisure Sports Professional in Sports College. Journal of Shanghai University of Sport, 2010, (1): 21-24

[6] Chen Qi, Ni Yike, et al. Reflections on Leisure Sports Talent Cultivation. Physical Education, 2008, (7): 5-10

[7] Zeng Dongmei, Xi Hongjian, Huang Guoxun, et al. Construction of Professional Training Programs, Tsinghua University Education Research, 2002, (5) 